\title{
Geostatistical analysis of soil properties in a secondary tropical dry forest, St. Lucia, West Indies
}

\author{
Otto J. Gonzalez and Donald R. Zak \\ School of Natural Resources and Environment, University of Michigan, Ann Arbor, Michigan 48109-1115, USA
}

Received 9 August 1993. Accepted in revised form 28 February 1994

Key words: available phosphorus, geostatistics, nitrogen mineralization, nitrification, organic carbon, spatial variation, tropical dry forest

\begin{abstract}
Spatial variability of soil properties directly influences forest growth. However, spatial variation in soil properties has not been studied within tropical dry forests. As such, it is unclear whether soil properties, like moisture and $\mathrm{N}$ availability, display spatial variation at scales similar to that of other ecosystems. To gain insight into this variation, we established a $56 \times 56 \mathrm{~m}$ sampling grid in tropical dry forest on the Caribbean island of St. Lucia. Samples collected at 4-m intervals were analyzed for forest floor mass, soil texture, pH, organic C, net $\mathrm{N}$ mineralization, net nitrification and available $\mathrm{P}$. Geostatistical procedures were used to determine spatial autocorrelation of the aforementioned properties and processes. Semivariogram parameters were used in a block kriging procedure to produce spatial maps of soil properties. At the scale of our study, most soil properties exhibited spatial autocorrelation at distances of $24 \mathrm{~m}$ or less. Varying degrees of similarity were found between patterns of forest floor mass, organic $\mathrm{C}$, net $\mathrm{N}$ mineralization, net nitrification and available P. No similarity was found between soil texture or $\mathrm{pH}$ and other properties. Fine-scale spatial patterns of net $\mathrm{N}$ mineralization and net nitrification are likely driven by overstory litter inputs, rather than variation in soil texture and water availability.
\end{abstract}

\section{Introduction}

Soils in tropical regions display more spatial variation than previously suggested by the literature (Richter and Babbar, 1991). This variation directly controls plant growth and is likely equivalent to, or greater than, that of soils in temperate regions. Tropical dry forests are particularly important because about $40 \%$ of the earth's tropical and subtropical lands are dominated by open or closed forest, of which $42 \%$ is dry forest (Murphy and Lugo, 1986). In these ecosystems, spatial variation in soil properties may be linked to differences in geological substrate, soil texture, topography and other factors affecting the development of soil and vegetation. Some of this variation may occur at the scale of kilometers, while other properties may vary over only a few meters or less (Robertson, 1987; Robertson et al., 1988; Trangmar et al., 1985; Yost et al., 1982). Recognizing spatial variation in soil properties is necessary for better understanding the spatial distribution of plants within an ecosystem and making more precise estimates of soil properties.

The causes of spatial variation differ according to scale. In Guanica, a subtropical dry forest in Puerto Rico, Lugo et al. (1978) found significant differences in soil properties associated with dry forest communities. For example, scrub forest occurred on the sandy soils, which had a low water holding capacity, while a transition between deciduous and semi-evergreen forest grew on soils with a high clay content and water holding capacity. Thus, the spatial distribution of vegetation at a landscape level in dry forest reflected variation in soil properties. On a finer scale, net nitrogen (N) mineralization rates, as well as organic carbon (C) and other soil properties in a tropical dry forest in India were related to slope position (Raghubanshi, 1992).

Classical statistical procedures assume independence among samples. Values for soil properties, however, are not randomly distributed within ecosystems or across landscapes; they are regional in their distribu- 
tion. As such, some soil samples are more similar than others based on the distance separating their locations. While this intuitive concept is not new or surprising, it is usually not considered when measuring or estimating values for ecological properties (Legendre and Fortin, 1989; Robertson, 1987). Geostatistical procedures account for spatial autocorrelation and can be used to estimate the spatial distribution of soil properties. By utilizing geostatistical procedures one can recognize the spatial dependence of various soil properties, improving precision and accuracy when estimating values for a region or for points not sampled.

Little is known about the spatial variation of soil properties in tropical dry forest ecosystems. Consequently, examining their spatial distribution may determine how they influence each other, leading to better understanding of the role they play in plant growth and ecosystem-level processes. Our objective was to examine the spatial variation in soil properties in a tropical dry forest ecosystem, and to determine the scale at which they became spatially independent. To accomplish this, we used geostatistical techniques to study spatial variation of soil properties in a tropical dry forest in St. Lucia, West Indies. We also compare values for soil properties in our study with those reported for other tropical dry forests.

\section{Study area}

The island nation of St. Lucia $\left(14^{\circ} \mathrm{N}, 61^{\circ} \mathrm{W}\right)$ is located in the eastern part of the Caribbean Sea. Its mountainous landscape is covered with a mix of banana agriculture and various types of forest vegetation. Although only $42.5 \mathrm{~km}$ long and $21 \mathrm{~km}$ across at its widest point, St. Lucia hosts seven Holdridge Life Zones (Organization of American States, 1987), because of drying coastal winds, orographic rain, and steep topography.

The island is volcanic in origin, and our study area was located in an area of andesitic agglomerate and tuff parent materials (Organization of American States, 1987). Soils formed in these materials were primarily Franciou Stony Clay and Hardy Clay (Stark et al., 1966). These soils are classified as an Inceptisol and a Vertisol, respectively (Ahmad, 1990).

The tropical dry forest life zone and the transition to very dry tropical forest cover about $34 \%$ of the island (average temperature $26^{\circ} \mathrm{C}$, annual rainfall 1000 to $2000 \mathrm{~mm}$; Organization of American States, 1987). Most of this area, however, is dominated by a secondary scrub forest, the result of many decades of repeated harvesting and agricultural abandonment. We located a small stand (ca. 0.5 ha) of relatively undisturbed secondary tropical dry forest near the community of Lumiere on the east coast of St. Lucia. Striking differences in species composition, canopy height, forest structure and tree diameter distribution were evident when comparing the more developed forest vegetation of our study site to the nearby scrub forest vegetation (O. Gonzalez 1991, personal observation).

A number of the dominant tree species (e.g., Inga laurina, Ocotea membranaceae), found in this site were not encountered in the more disturbed portions of the dry zone, but can be found in remaining moist forests. Vegetation in areas surrounding our study site had been under the pressure of forest cutting and livestock grazing, and is shorter, more open, and virtually absent of large trees; the majority of stems were $4 \mathrm{~cm}$ or less in diameter (O. Gonzalez 1991, personal observation). While precise dates of disturbance are unknown, a remnant charcoal pit within our study site indicates that clearcutting for fuelwood had occurred in the past.

Canopy dominants in our study site consist of Inga laurina (Sw.) Willd., Ocotea membranaceae (Sw.), and Coccoloba swartzii Meissner in DC. with a sub canopy dominated by Inga laurina, Ocotea membranaceae and Chrysophyllum argenteum Jacq. The most abundant species in the understory were $O$. membranaceae, I. laurina, C. argenteum and C.swartzii. The shrub layer consisted mainly of $O$. membranaceae, C. argenteum, C. swartzii, Myrcia deflexa (Poiret) DC., and other Myrcia species. Diameters-at-breast height $(1.3 \mathrm{~m})$ ranged from 1 to $45 \mathrm{~cm}$. The site had a slope varying between 25 to $49 \%$ with a west aspect.

\section{Field and laboratory methods}

In July 1990 , we established a $56 \times 56 \mathrm{~m}$ grid and collected samples at 4-m intervals (225 sample points). We collected forest floor (leaves, small twigs and reproductive structures) samples using a $0.25 \times 0.25$ $\mathrm{m}$ frame and extracted surface soil samples ( 0 to 10 $\mathrm{cm}$ of mineral soil) using a Dutch auger. Forest floor and soil samples were each stored in porous Tydac bags. All samples were transported to the University of Michigan for analyses. Forest floor samples were oven dried at $70^{\circ} \mathrm{C}$ to a constant weight, whereas soil samples were air dried in their Tydac bags. Soil aggregates were broken manually using a mortar and pestle, prior to passing all material through a 2-mm sieve. All analyses were conducted on air-dried soil. 
Soil texture was determined using a 40-g subsample following the hydrometer procedure described by Gee and Bauder (1986). Soil pH was measured in a 1:1 soil:water (deionized) mixture with a Beckman $\mathrm{pHI} 70 \mathrm{pH}$ meter. Soil organic $\mathrm{C}$ was determined colorimetrically following dichromate oxidation (Nelson and Sommers, 1982). Available phosphorus ( $\left.\mathrm{PO}_{4}^{3-}-\mathrm{P}\right)$, was determined on a 2-g subsample of soil extracted with $12 \mathrm{~mL}$ of Bray's solution (Olsen and Sommers, 1982). The $P$ concentration of the centrifuged filtrate was determined using automated colorimetry (ALPKEM RFA 300, ALPKEM Corporation, Clackamas, Oregon).

Potential net $\mathrm{N}$ mineralization and nitrification were determined using an aerobic incubation technique. A $10-\mathrm{g}$ subsample of air-dried sieved soil was extracted with $2 \mathrm{M} \mathrm{KCl}$ (Keeney and Nelson, 1982). Initial $\mathrm{NH}_{4}^{+}-\mathrm{N}$ and $\mathrm{NO}_{3}^{-}-\mathrm{N}$ in the extracts were determined using automated colorimetry (ALPKEM RFA 300, ALPKEM Corporation, Clackamas, Oregon). A second set of subsamples $(10 \mathrm{~g})$ was brought to field capacity and incubated aerobically at $30^{\circ} \mathrm{C}$ for $49 \mathrm{~d}$. Weights at field capacity were recorded and incubated samples were maintained at these weights by one daily addition of deionized water. The selected incubation temperature of $30^{\circ} \mathrm{C}$ was high enough to allow increased rates of microbial activity, while not causing sample dessication. At the end of the, incubation period, samples were extracted with $2 \mathrm{M} \mathrm{KCl}$ and analyzed for $\mathrm{NH}_{4}^{+}-\mathrm{N}$ and $\mathrm{NO}_{3}^{--}-\mathrm{N}$ as described above. Potential net $\mathrm{N}$ mineralization was calculated as the increase in $\mathrm{NH}_{4}^{+}-\mathrm{N}$ and $\mathrm{NO}_{3}^{-}-\mathrm{N}$ over the $49 \mathrm{~d}$ incubation. Similarly, potential net $\mathrm{N}$ nitrification was the increase in $\mathrm{NO}_{3}^{-}-\mathrm{N}$ alone.

\section{Statistical and geostatistical methods}

Geostatistical methods require using data sets with normally distributed values. Data for each soil property were checked for normality and transformed if appropriate. In order to test for spatial dependence among sample points, we computed semivariograms for each soil property. A semivariogram is a graphical indication of the degree of spatial autocorrelation measured for a particular random variable in a sample set; it is a statistical model of spatial dependence (Rossi et al., 1992). A semivariogram displays the change in the semivariance between samples as the distance between them increases. Semivariance is defined as half the expected squared difference between sample values separated by a given distance or lag, $\mathrm{h}$ (Burgess and Webster 1980a; Trangmar et al., 1985; Vieira et al., 1983). The semivariance $(\gamma)$ at a given lag (h) is estimated using the following equation (Equation 1; Trangmar et al., 1985; Vieira et al., 1983):

$$
\gamma(\mathrm{h})=\frac{1}{2 \mathrm{~N}(\mathrm{~h})} \sum_{\mathrm{i}=1}^{\mathrm{N}(\mathrm{h})}\left[\mathrm{z}\left(\mathrm{x}_{\mathrm{i}}\right)-\mathrm{z}\left(\mathrm{x}_{\mathrm{i}}+\mathrm{h}\right)\right]^{2}
$$

Where $\mathrm{Z}$ is a regionalized variable (i.e., a soil property), $z\left(x_{i}\right)$ is a measured sample at point $x_{i}, z\left(x_{i}+h\right)$ is a measured sample at point $x_{i}+h$, and $N(h)$ is the number of pairs separated by distance or lag, $h$ (Robertson, 1987).

A semivariogram graphically expresses the relationship between the semivariance and the distance between points. It has three statistics: the nugget, sill, and range (Burgess and Webster, 1980a). The nugget, also known as the stochastic variance, represents variability not accounted for by the model either, because of fine-scale variability (i.e., less than the sampling interval), or measurement error (Trangmar et al., 1985). If the semivariogram curve passes through the origin, it fully describes the spatial dependency of the soil property, with spatial dependency accounting for all of the semivariance within the range. Usually, however, the curve does not pass through the origin and this discontinuity is called the 'nugget' or 'nugget effect'. The range (also called the zone of influence), defined as the distance at which the sill is achieved, represents the average maximum distance over which two samples are related (Yost et al., 1982). In this paper, we define the main zone of influence as the range where the data most closely fit the model or where the model begins to level off (i.e. where the slope approaches zero). This represents the distance within which spatial autocorrelation is the strongest. The sill, or structural variance, is the value of the semivariance where the model levels off (Trangmar et al., 1985), and approximates the total variance in the sample. The percent of the sill accounted for by the nugget is sometimes called the relative nugget effect (Isaaks and Srivastava, 1989).

Appropriate models to describe the semivariance were selected through a least-squares best-fit procedure, selecting the model with the highest coefficient of determination and lowest nugget variance. The model and its parameters were used in a kriging procedure to estimate values for points in space that were not sampled. Kriging is a procedure in which a weighted 
average of values of sampled points in a neighborhood is used to estimate a value for an unsampled point in that neighborhood (Trangmar et al., 1985). We used block kriging (Burgess and Webster, 1980b; Trangmar et al., 1985) to produce spatial maps of soil properties. In this procedure, values are estimated for areas or blocks with $\mathrm{x}_{0}$ as the block center, rather than for points as in punctual kriging (Equation 2; Trangmar et al., 1985). We chose to estimate values for unsampled locations using block kriging rather than punctual kriging, because block kriging allows the division of the sample area into discrete blocks for which an estimate is provided. Thus, values are estimated for small regions, rather than points. This approach is desirable when nugget variances are high, and when an average value estimate for each square on a sampling grid is preferred over an estimate for each point at some regular interval (Burgess and Webster, 1980b).

$$
\hat{\mathbf{z}}(\mathrm{V})=\sum_{\mathrm{i}=1}^{\mathrm{N}} \lambda_{\mathrm{i}} \mathrm{z}\left(\mathrm{x}_{\mathrm{i}}\right)
$$

The kriged value for a soil property $Z$ for any block $\mathrm{V}$ is a weighted average (where $\lambda_{i}$ is the weight) of the measured sample values $x_{i}$ in the neighborhood of the block (Trangmar et al. 1985). The kriged values were then used to produce maps with isopleths or regions of different values for each soil property. These maps display the regionalized nature of the measured soil variable. All geostatistical procedures and mapping were performed using a personal computer-based geostatistical software package (GS +, Gamma Design Software, Plainwell, Michigan).

\section{Results}

All variables, except available $P$, exhibited no serious deviations from normality. Available $\mathrm{P}$ was lognormally distributed, and was $\log$ transformed $(\ln x)$ and back transformed $\left(\mathrm{e}^{\mathrm{x}}\right)$ for geostatistical analysis. The range of values and the mean value obtained for each soil property is displayed in Table 1. Textural classes ranged from sandy loam to clay, although all samples except for two were in the loam or heavier classes. Potential net mineralization and nitrification were equivalent because virtually all mineralized $\mathrm{NH}_{4}^{+}$was oxidized to $\mathrm{NO}_{3}^{-}$(Table 1).

For most properties, half or less of the observed variation was due to spatial autocorrelation, as evidenced by the height of the intercepts above the origin (i.e., relative nugget effect; Fig. 1, Table 2). Forest floor, organic $\mathrm{C}$ and available $\mathrm{P}$ were most strongly autocorrelated at distances of $24 \mathrm{~m}$ or less (Fig. 1, Table 2). Silt + clay exhibited a zone of influence of $20 \mathrm{~m}$, while autocorrelation for $\mathrm{pH}$ extended to $42 \mathrm{~m}$. Potential net $\mathrm{N}$ mineralization and nitrification were almost identical, each with zones of influence of about $13 \mathrm{~m}$ (Fig. 1, Table 2).

Nugget variances for net $\mathrm{N}$ mineralization and net nitrification account for $69 \%$ and $66 \%$ of the sill, respectively. Thus, $31 \%$ of the mineralization variance and $34 \%$ of the nitrification variance may be accounted for by spatial autocorrelation (Figs. IE and 1F). The semivariogram for net $\mathrm{N}$ mineralization suggests that some autocorrelation exists between samples less than $36 \mathrm{~m}$ apart and that the strongest autocorrelation is between samples less than $13 \mathrm{~m}$ apart. This distance $(13 \mathrm{~m})$ represents the strongest zone of influence also for net nitrification. Available P displayed a lower relative nugget effect with the nugget accounting for $55 \%$ of the sill (Fig. 1G); it exhibited a main zone of influence of $24 \mathrm{~m}$.

Maps of soil properties produced from the block kriging procedure are presented in Figure 2. Because the majority of mineralized $\mathrm{N}$ was oxidized to $\mathrm{NO}_{3}^{-}$, spatial representations of mineralization and nitrification are almost identical (see Figs. 2E and 2F). There also appears to be some correspondence between these processes and organic C (Fig. 2D). Areas of low net mineralization and nitrification in the upper right of the plot and in the center of the plot, roughly correspond to two of the regions lowest in organic $\mathrm{C}$. The area of low mineralization and nitrification in the upper right region of the plot also corresponds to a region of low available $P$ (Fig. 2G). There is some correspondence between the regions of high mineralization and nitrification in the east and west of the forest patch and some of the regions highest in organic $\mathrm{C}$. The high region of organic $\mathrm{C}$ in the east connects with another high region in the top-center of the plot (Fig. 2D). A similar north to east pattern is repeated for available phosphorus (Fig. $2 \mathrm{G})$. Forest floor mass is high in the top-center area, an area also high in organic $\mathrm{C}$ and available $\mathrm{P}$ (Figs. $2 A$ and $2 G$ ).

Soil silt + clay and $\mathrm{pH}$ exhibited spatial patterns, although we did not observe spatial association between these properties or with the other measured properties. Values for $\mathrm{pH}$ in the range 5.5-6.0 (medium acid to slightly acid) were concentrated in the lower left section of the plot, while those between 6.5-7.0 (very slightly acid to neutral) occurred mainly in the 
Table 1. Summary statistics for soil properties in a patch of tropical dry forest in St. Lucia

\begin{tabular}{lllllll}
\hline Soil property & $\mathrm{N}$ & Mean & Min & Max & SD & Median \\
\hline Forest floor $\left(\mathrm{g} \mathrm{m}^{-2}\right)$ & 225 & 779 & 227 & 2363 & 375.6 & 694 \\
Silt + clay $(\%)$ & 223 & 65.9 & 41.8 & 87.6 & 7.29 & 66.2 \\
$\mathrm{pH}$ & 224 & 6.32 & 5.18 & 7.59 & 0.42 & 6.29 \\
Organic C $(\%)$ & 223 & 3.3 & 1.3 & 6.0 & 0.9 & 3.2 \\
Mineralization $\left(\mu \mathrm{g} \mathrm{N} \mathrm{g}^{-1}\right)$ & 218 & 129 & 0 & 237 & 42.9 & 127.8 \\
Nitrification $\left(\mu \mathrm{g} \mathrm{NO}_{3}^{-}-\mathrm{N} \mathrm{g}^{-1}\right)$ & 218 & 137 & 0 & 238 & 43.6 & 137.1 \\
Available $\mathrm{P}\left(\mathrm{mg} \mathrm{kg}^{-1}\right)$ & 214 & 1.23 & 0.20 & 5.98 & 1.17 & 0.87 \\
\hline
\end{tabular}

Table 2. Spatial statistics for soil properties in a patch of tropical dry forest in St. Lucia

\begin{tabular}{llllllll}
\hline Soil property & Nugget & Sill & $\begin{array}{l}\text { Relative } \\
\text { nugget effect } \\
(\%)\end{array}$ & $\begin{array}{l}\text { Main zone of } \\
\text { influence } \\
(\mathrm{m})\end{array}$ & $\begin{array}{l}\text { Range } \\
(\mathrm{m})\end{array}$ & Model & $\mathrm{r}^{2}$ \\
\hline Forest floor & 430 & 605.9 & 71 & 24 & 18.48 & Exponential & 0.948 \\
Silt + clay & 40.7 & 52.3 & 78 & 20 & 28.56 & Spherical & 0.841 \\
pH & 0.089 & 0.213 & 42 & 42 & 57.74 & Spherical & 0.972 \\
Organic C & 0.71 & 0.96 & 74 & 24 & 71.20 & Spherical & 0.806 \\
Mineralization & 1300 & 1897 & 69 & 13 & 13.67 & Spherical & 0.607 \\
Nitrification & 1250 & 1896 & 66 & 13 & 13.42 & Spherical & 0.652 \\
Available P & 0.241 & 0.437 & 55 & 24 & 48.18 & Exponential & 0.923 \\
\hline
\end{tabular}

upper right and right. Values in the 6.0-6.5 (slightly acid to very slightly acid) were found in the remaining area of the plot.

\section{Discussion}

Spatial variation of soil reflects and influences the geographic distribution of individual plants and entire ecosystems. In the tropical dry forest we studied, soil properties were generally comparable to those reported for similar tropical forests, suggesting that some generalizations can be drawn regarding theses poorly described soils. Moreover, the spatial representation of soil properties from our geostatistical analyses demonstrated that soil texture was relatively uniform within the plot, while soil organic matter content, $\mathrm{N}$ transformations, and $\mathrm{P}$ availability displayed substantial variation at the scale of $24 \mathrm{~m}$ or less. These results indicate that such variation is likely driven by the spatial distribution of individual trees and their litter inputs, and do not result from fine-scale variation in physical soil properties like soil texture or water holding capacity.

\section{Soil properties in tropical dry forests}

In our study, soil $\mathrm{pH}$ values were lower than the $\mathrm{pH}$ 7.8 reported by Lugo and Murphy (1986) in the Guanica dry forest in Puerto Rico, which was underlain by limestone. Organic $\mathrm{C}$ was comparable between these dry forests (approximately 3\%; Lugo and Murphy, $1986)$, and to that reported in India (2\%; Srivastava and Singh, 1989, 1991). However, our values were lower than those reported for seasonally dry forest in Belize (7 and 10\%; Arnason and Lambert, 1982), and for microsites in Guanica where detritus had accumulated (9 to 11.5\%; Lugo and Murphy, 1986).

In the tropical dry forest we studied, potential net $\mathrm{N}$ mineralization and nitrification averaged $2.64 \mathrm{~N} \mu \mathrm{g}$ $\mathrm{g}^{-1} \mathrm{~d}^{-1}$ and $2.78 \mathrm{NO}_{3}^{-}-\mathrm{N} \mu \mathrm{g} \mathrm{g}^{-1} \mathrm{~d}^{-1}$, respectively. In rain forest in Costa Rica, Robertson (1984) used a shorter incubation period ( $9 \mathrm{~d}$ ) and lower temperature 

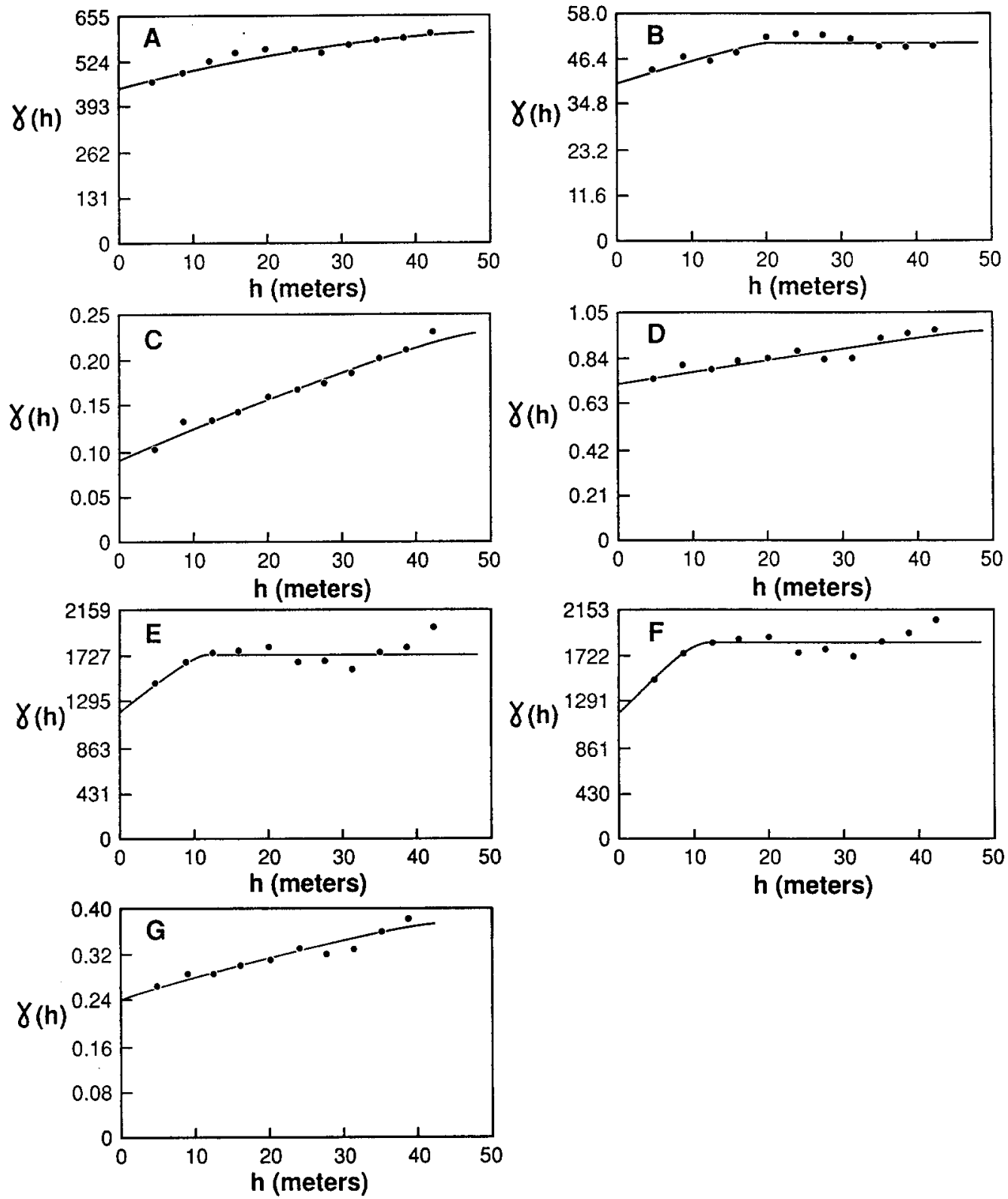

Fig. 1. Semivariograms of soil properties in a patch of tropical dry forest, St. Lucia West Indies. Solid lines are models fitted by a least -squares analysis. A Forest floor. Exponential model $\left(\mathrm{r}^{2}=0.948\right): \gamma(\mathrm{h})=430+605.9\left(1-\mathrm{e}^{(-\mathrm{h} / 18.48)}\right]$. B $\%$ Silt + clay. Spherical model $\left(\mathrm{r}^{2}=0.841\right)$ : $\gamma(\mathrm{h})=40.7+52.3\left(1.5(\mathrm{~h} / 28.56)-0.5(\mathrm{~h} / 28.56)^{3}\right]$. C. Soil $\mathrm{pH}$. Spherical model $\left(\mathrm{r}^{2}=0.972\right): \gamma(\mathrm{h})=0.089+0.213\left[1.5(\mathrm{~h} / 57.74)-0.5(\mathrm{~h} / 57.74)^{3}\right]$. D. \% Organic carbon. Spherical model $\left(\mathrm{r}^{2}=0.806\right): \gamma(\mathrm{h})=0.71+0.96\left[1.5(\mathrm{~h} / 71.20)-0.5(\mathrm{~h} / 71.20)^{3}\right]$. E. Mineralization. Spherical model $\left(\mathrm{r}^{2}\right.$ $=0.607): \gamma(\mathrm{h})=1300+1897\left[1.5(\mathrm{~h} / 13.67)-0.5(\mathrm{~h} / 13.67)^{3}\right]$. F. Nitrification. Spherical model $\left(\mathrm{r}^{2}=0.652\right): \gamma(\mathrm{h})=1250+1896[1.5(\mathrm{~h} / 13.42)-$ $\left.0.5(\mathrm{~h} / 13.42)^{3}\right]$. G. Available phosphorus. Exponential model. $\left(\mathrm{r}^{2}=0.923\right): \gamma(\mathrm{h})=0.241+0.437\left[1-\mathrm{e}^{(-\mathrm{h} / 48.18)}\right]$.

$\left(24{ }^{\circ} \mathrm{C}\right)$, but found similar rates in 31 and $60+$ year old stands $\left(3 \mu \mathrm{g} \mathrm{g}^{-1} \mathrm{~d}^{-1}\right)$. In most of our samples, nitrification accounted for over $90 \%$ of mineralization, similar to Robertson (1984) where $\mathrm{NO}_{3}^{-}-\mathrm{N}$ accounted for $95 \%$ of mineralized $\mathrm{N}$. In a tropical deciduous forest in Mexico, potential $\mathrm{N}$ mineralization ( $7 \mathrm{~d}$ incu- bation at $20{ }^{\circ} \mathrm{C}$ ) ranged from 0.30 to $4.12 \mu \mathrm{g}, \mathrm{g}^{-1}$ $\mathrm{d}^{-1}$ over a two year period, with nitrification representing only a small percentage of mineralized $\mathrm{N}$ (Garcia-Mendez et al., 1991). For a range of tropical forest sites in India, Raghubanshi (1992), using a 30$\mathrm{d}$ field incubation, found rates ranging from 0 to 1.1 

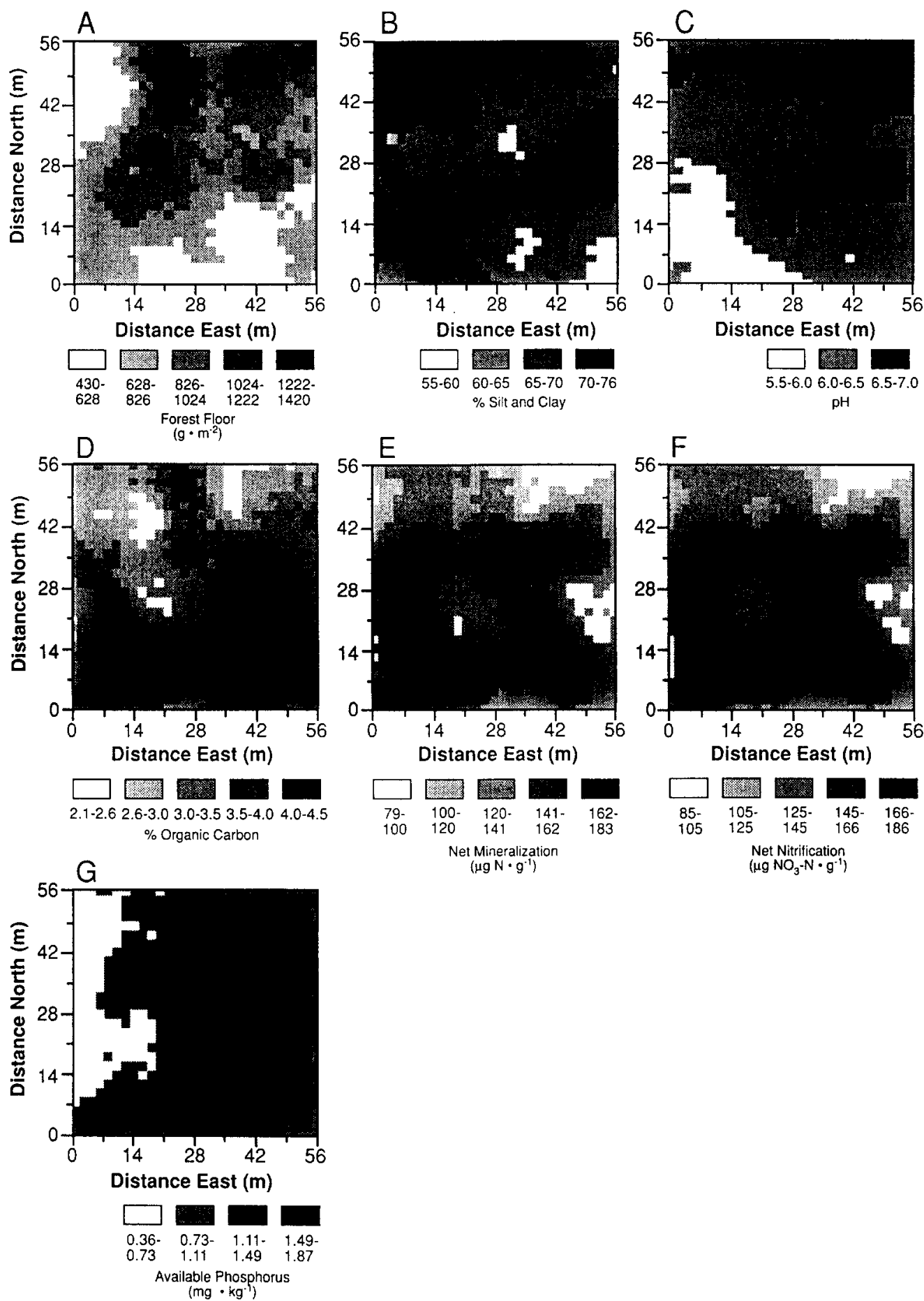

Fig. 2. Regions of values for soil properties block kriged with $2 \mathrm{~m}$ between block centers for a patch of tropical dry forest in St. Lucia, West Indies. (range of estimation standard deviations given for mapped values) A. Forest floor (136.76-154.72 $\mathrm{g} \mathrm{m}^{-2}$ ). B. \% Silt + clay (2.52-2.84 \%). C. Soil pH (0.131-0.157). D. \% Organic carbon (0.316-0.342 \%). E. Mineralization (17.05-23.08 ( $\left.\mu \mathrm{g} \mathrm{g}^{-1}\right)^{2}$ N). F. Nitrification (17.19-23.71 ( $\mu \mathrm{g} \mathrm{NO}_{3}^{-}-\mathrm{Ng}$ ). G. Available phosphorus $\left(1.02-1.03 \mathrm{mg} \mathrm{kg}^{-\mathrm{l}^{2}}\right.$ ) 
$\mu \mathrm{g} \mathrm{g}^{-1} \mathrm{~d}^{-1}$ for net $\mathrm{N}$ mineralization and 0 to 0.633 $\mu \mathrm{g} \mathrm{g}^{-1} \mathrm{~d}^{-1}$ for net nitrification. Rates obtained under different conditions must be compared and evaluated carefully, because rates average differently, depending on incubation length and temperature.

Available $P$ had a wide range with a mean of 1.23 $\mathrm{mg} \mathrm{kg}^{-1}$ According to Lugo and Murphy (1986), 1.3\% of total $P$ in surface soil in Guanica was extractable. Based on their determination of $0.57 \mathrm{mg} \mathrm{g}^{-1}$ for surface total P, available $P$ in Guanica dry forest was 7.41 $\mathrm{mg} \mathrm{kg}{ }^{-1}$. While considerably higher than our mean value, it is not far beyond our maximum value of 5.98 $\mathrm{mg} \mathrm{kg}^{-1}$.

\section{Spatial variation within a tropical dry forest}

General similarity of patterns can be seen when comparing net $\mathrm{N}$ mineralization and net nitrification with organic $\mathrm{C}$, forest floor mass, and available $\mathrm{P}$. One would expect some similarity between $\mathrm{N}$ transformations and organic $\mathrm{C}$ because they both result from the decomposition of organic matter. There are other variables, not measured or accounted for in this analysis, that may also influence the spatial distribution of organic $\mathrm{C}$ and $\mathrm{N}$ mineralization. Because of the different plant species present, there may be spatial variation in the physical and chemical quality of the leaf litter. In a temperate forest dominated by Eastern hemlock (Tsuga canadensis) and tulip tree (Liriodendron tulipifera), Boettcher and Kalisz (1990) found that individual trees, primarily through deposition and decomposition of litter, significantly influenced values for $\mathrm{pH}$ and net $\mathrm{N}$ mineralization in the surface soil.

The rate of leaf litter decomposition may differ among species (La Caro and Rudd, 1985; Wiegert and Murphy, 1970) due to initial lignin content or the presence of polyphenolic compounds (Melillo et al., 1982; Palm and Sanchez, 1990, 1991). Such differences could contribute to spatial variation in soil chemical properties. In the dry tropical forest we studied, some leaves apparently decompose more rapidly than others (O. Gonzalez, pers. obs.). For example, canopy species Cordia sulcata and Ocotea membranaceae leaf litters are thicker and are longer lived than those of Inga laurina, also found in the canopy. Another source of unaccounted variation is the nutrient contribution from fine root turnover, which was shown to be substantial in a tropical dry forest in India (Singh and Singh, 1991).

The magnitude of variation for net $\mathrm{N}$ mineralization and nitrification is comparable to the landscape-level variation found by Zak et al. (1986) between two dif- ferent temperate forest ecosystems. Robertson et al. (1988), however, found similar magnitude of variation within an old field in Michigan. The strong normality (mean about equal to median) and relative narrowness (about $70 \%$ of values fall within one standard deviation from the mean) of the distributions for net $\mathrm{N}$ mineralization and net nitrification in our study indicate that the mean is statistically acceptable as a good representative of the stand, even though the magnitude of variation is equivalent to that found at the landscape level in some temperate forests and old fields (Robertson et al., 1988; Zak et al., 1986).

Slope, which influences the surface transport of water and products of decomposition, also may be a cause of spatial variation. In an upland pin oak (Quercus ellipsoidalis) ecosystem, Zak et al. (1991) found local topography influenced nitrification with higher rates in well-drained top and mid-slope positions compared with an imperfectly drained bottom-slope position. Nitrogen mineralization and nitrification rates displayed distinct patterns in an old-field ecosystem with the highest rates associated with swales (Robertson et al., 1988). In a dry tropical forest in India, Raghubanshi (1992) reported organic C to vary topographically, with the highest amount being in the top- slope position, followed by mid-slope and foot-slope; rates of $\mathrm{N}$ mineralization displayed a similar trend. Along with topography, forest vegetation differed in the aforementioned studies, perhaps contributing to observed differences in soil organic $\mathrm{C}$ and rates of $\mathrm{N}$ mineralization. In our study, slope varied from 25 to $49 \%$; however, $\mathrm{N}$ transformations and other soil properties did not appear to vary with topography. Alternatively, our laboratory estimates of mineralization and nitrification may not reflect the true variation of these processes in situ.

Spatial autocorrelation at relatively short distances (e.g., $24 \mathrm{~m}$ ) highlights the importance of very local values for ecosystem properties and processes. By linking soil properties, processes, and scale, one might be able to identify effects on forest growth. The patterns of organic $\mathrm{C}$, net $\mathrm{N}$ mineralization, net nitrification and available $\mathrm{P}$ appear to be the result of biotic influences (e.g., leaf and fine root litter input) accumulating over an unknown length of pedogenic time. While these biotically driven patterns display some similarities with each other, they show no similarity with soil silt + clay or $\mathrm{pH}$. For most of the plot, the variation in silt + clay was only $20 \%$. Thus, the main similarity in patterned variation observed in the plot appears to be independent of silt + clay and $\mathrm{pH}$. The observed patterns of soil properties and processes have 
developed over time, and are likely influenced by the effects of previous forest stands on the site and prior disturbances.

The fine-scale spatial variation of soil organic $\mathrm{C}$, available $P$, and the processes of net $N$ mineralization and net nitrification, appear to be under biological control, rather than physical control. Evidence for our conclusion results from the poor correspondence between soil texture and the aforementioned soil parameters. As such, spatial variation of certain soil properties in this secondary dry forest may be more influenced by present and past vegetation, rather than soil texture or mineralogy. By using geostatistical procedures, we have been able to make a more precise determination of these patterns than through classical statistical procedures, and thus can better understand how these patterns may be linked biologically.

\section{Summary}

Soil properties in the secondary tropical dry forest we studied exhibited some spatial autocorrelation at a distance of $24 \mathrm{~m}$ or less. Specifically, spatial autocorrelation was strongest for soil $\mathrm{pH}$ and available $\mathrm{P}$, less for net $\mathrm{N}$ mineralization, nitrification and forest floor mass, and least for organic $\mathrm{C}$ and soil silt + clay. Even at the scale of $4 \mathrm{~m}$, a significant proportion of the observed variation could not be accounted for by spatial dependency. Such stochastic variation would be expected to be greatest in ecosystems with diverse species, a non-uniform canopy, and differences in soil physical factors, and least where vegetation is fairly uniform in structure and species composition.

Maps of soil properties show varying degrees of similarity among patterns of organic $\mathrm{C}$, net $\mathrm{N}$ mineralization, net nitrification and available $\mathrm{P}$, but no similarity with \% silt + clay or $\mathrm{pH}$. Results suggest that spatial patterns of soil $\mathrm{N}$ transformations are likely driven by variation in organic matter inputs from plant litter production. The relatively narrow range of soil textures combined with a small degree of silt + clay spatial variation, suggests that the variation observed in $\mathrm{N}$ transformation was not related to fine-scale differences in soil texture or soil water holding capacity.

\section{Acknowledgements}

We are grateful to the Population Environment Dynamics Project, University of Michigan, for funding our study. We especially thank Project Director Gayl Ness, and Project Associate Sandy Thomas. In St. Lucia, the late Gabriel L Charles, former Chief Forest and Lands Officer, was critical to the success of our research; we shall miss him. Chief Forest Officer Brian James also supported our endeavors. Forest Range Officer Cornelius Isaac was extremely helpful in the field, and offered useful insights. We also thank Laurent Jean-Pierre of the St. Lucia National Trust, for help with herbarium specimens, and Elwin Polemis for field assistance. At the University of Michigan, our project benefited from the efforts of Brigette Gotts, Jeffrey Hacala, Bill Holmes, Dawn Majewski, Sandra Suarez, Kelly Caldwell, Susie Remold, and Andrew Kerr; we thank them all. A very special thanks goes to Diana L Randlett for her valuable support in all laboratory procedures, and Neil W MacDonald for his thoughtful advice throughout this study.

\section{References}

Ahmad N 1990 Soils of St. Lucia In Land Use Management Workshop Part 2, May 7-18, 1990, St. Lucia, Caribbean Sea. Forest Management and Conservation Project No. 868 12151. Canadian International Development Agency.

Arnason J T and Lambert J D H 1982 Nitrogen cycling in the seasonally dry forest zone of Belize, Central America. Plant and Soil $67,333-342$.

Boettcher S E and Kalisz P J 1990 Single-tree influence on soil properties in the mountains of eastern Kentucky. Ecology 71, 1365-1372.

Burgess T M and Webster R 1980a Optimal interpolation and isarithmic mapping of soil properties. I. The semi-variogram and punctual kriging. J. Soil Sci. 31, 315-331.

Burgess T M and Webster R 1980b Optimal interpolation and isarithmic mapping of soil properties. II. Block kriging. J Soil Sci. 31, 333-341.

Garcia-Mendez G, Maass J M, Matson P A and Vitousek P M 1991 Nitrogen transformations and nitrous oxide flux in a tropical deciduous forest in Mexico. Oecologia 88, 362-366.

Gee G W and Bauder J W 1986 Particle-size analysis (Chap.15). In Methods of Soil Analysis, Part 1. Physical and Mineralogical Methods - Agronomy Monograph No. 9 (2nd Edition). Ed. A. Klute. pp 383-411 American Society of Agronomy - Soil Science Society of America.

Isaaks E H and Srivastava R M 1989 Applied Geostatistics. Oxford University Press, New York. 561 p.

Keeney D R and Nelson D W 1982 Nitrogen-Inorganic forms (Chap 33). In Methods of Soil Analysis, Part 2. Chemical and Microbiological Properties (2nd Edition). Eds. A L Page, R H Miller and D R Keeney. pp 643-698 American Society of Agronomy - Soil Science Society of America.

La Caro F and Rudd R L 1985 Leaf litter disappearance rates in Puerto Rican montane rain forest. Biotropica 17, 269-276.

Legendre $P$ and Fortin M-J 1989 Spatial pattern and ecological analysis. Vegetatio $80,107-138$. 
Lugo A E and Murphy P G 1986 Nutrient dynamics of a Puerto Rican subtropical dry forest. J. Trop. Ecol. 2, 55-72.

Lugo A E, Gonzalez-Liboy J A, Cintron B and Dugger K 1978 Structure, productivity, and transpiration of a subtropical dry forest in Puerto Rico. Biotropica 10, 278-291.

Mellilo J M, Aber J D and Muratore J F 1982 Nitrogen and lignin control of hardwood leaf litter decomposition dynamics. Ecology 63, 621-626.

Murphy P G and Lugo A E 1986 Ecology of a tropical dry forest. Annu. Rev. Ecol. System. 17, 67-88.

Nelson D W and Sommers L E 1982 Total organic, organic carbon, and organic matter (Chap. 29). In Methods of Soil Analysis, Part 2. Chemical and Microbiological Properties (2nd Edition). Eds. A L Page, R H Miller and D R Keeney. pp 539-579 American Society of Agronomy -Soil Science Society of America.

Olsen S R and Sommers L E 1982 Phosphorus (Chap. 24). In Methods of Soil Analysis, Part 2. Chemical and Microbiological Properties (2nd Edition). Eds. A L Page, R H Miller and D R Keeney. pp 403-430 American Society of Agronomy -Soil Science Society of America.

Organization of American States 1987 Saint Lucia Development Atlas. Organization of American States, Washington, D.C. 41 p. + maps.

Palm C A and Sanchez P A 1990 Decomposition and nutrient release patterns of the leaves of three tropical legumes. Biotropica 22 . 330-338.

Palm C A and Sanchez P A 1991 Nitrogen release from the leaves of some tropical legumes as affected by their lignin and polyphenolic contents. Soil Biol. Biochem. 23, 83-88.

Raghubanshi A S 1992 Effect of topography on selected soil properties and nitrogen mineralization in a dry tropical forest. Soil Biol, Biochem. 24, 145-150.

Richter D D and Babbar L I 1991 Soil diversity in the tropics. Adv. Ecol. Res. 21, 315-389.

Robertson G P 1984 Nitrification and nitrogen mineralization in a lowland rainforest succession in Costa Rica, Central America. Oecologia 61, 99-104.

Robertson G P 1987 Geostatistics in ecology: Interpolating with known variance. Ecology 68, 744-748.

Robertson G P, Huston M A, Evans F C and Tiedje J M 1988 Spatial variability in a successional plant community. patterns of nitrogen availability. Ecology 69, 1517-1524
Rossi R E, Mulla D J, Journel A G and Franz E H 1992 Geostatistical tools for modeling and interpreting ecological spatial dependence. Ecol. Monogr. 62, 277-314.

Singh L and Singh J S 1991 Storage and flux of nutrients in a dry tropical forest in India. Ann Bot. 68, 275-284.

Srivastava S C and Singh J S 1989 Effect of cultivation on microbial carbon and nitrogen in dry tropical forest soil. Biol. Fertil. Soils 8, 343-348.

Srivastava S C and Singh J S 1991 Microbial C, N, and P in dry tropical forest soils: Effects of alternate land-uses and nutrient flux. Soil Biol. Biochem. 23, 117-124.

Stark J, Lajoie P and Green A J 1966 Soil and Land-Use Surveys No. 20 St. Lucia. The Regional Research Centre of the British Caribbean. Imperial College of Tropical Agriculture, University of the West Indies. Trinidad, West Indies. $49 \mathrm{p}$. + maps

Trangmar B B, Yost R S, and Uehara G 1985 Application of geostatistics to spatial studies of soil properties. Adv. Agron 38, 45-94.

Vieira S R, Hatfield J L, Nielsen D R and Biggar J W 1983 Geostatistical theory and application to variability of some agronomical properties. Hilgardia 51 (3), 1-75.

Wiegert- R G and Murphy P 1970 Effect of season, species, and location on the disappearance rate of leaf litter in a Puerto Rican rain forest (Chap H-5) In A Tropical Rain Forest, A Study of Irradiation and Ecology at El Verde, Puerto Rico. Eds. H T Odum and R F Pigeon. pp. H101-H104. U.S. Atomic Energy Commission.

Yost R S, Uehara G and Fox R L 1982 Geostatistical analysis of soil chemical properties of large land areas. I. Semi-variograms. Soil Sci. Soc. America J. 46, 1028-1032.

Zak D R, Pregitzer K S and Host G E 1986 Landscape variation in nitrogen mineralization and nitrification. Can. J. For. Res. 16, 1258-1263

Zak D R, Hairston A and Grigal D F 1991 Topographic influences on nitrogen cycling within an upland pin oak ecosystem. Forest Science $37,45-53$.

Section editor: B E Clothier 